\title{
Technological university in Brazil: examining the development and (de)construction of the model
}

${ }^{1}$ Luiz Marcelo de Lara, ${ }^{2}$ Celso Bilynkievycz dos Santos, ${ }^{3}$ Bruno Pedroso, ${ }^{4}$ Camila Lopes Ferreira, ${ }^{5}$ Luiz Alberto Pilatti
${ }^{1}$ Universidade Tecnológica Federal do Paraná https://orcid.org/0000-0002-9238-9740
${ }^{2}$ Universidade Estadual de Ponta Grossa https://orcid.org/0000-0003-2107-8299
${ }^{3}$ Universidade Estadual de Ponta Grossa https://orcid.org/0000-0002-7905-2393
${ }^{4}$ Universidade Tecnológica Federal do Paraná https://orcid.org/0000-0001-6314-8764
${ }^{5}$ Universidade Tecnológica Federal do Paraná https://orcid.org/0000-0003-2679-9191

\begin{abstract}
:
Based primarily on an analysis of laws and legal frameworks, this qualitative exploratory study aims to examine the development, context, construction, as well as deconstruction, of the technological university model in Brazil. The Federal University of Technology - Paraná (UTFPR) is the only technological university in the country. The analysis presented herein demonstrates that its development is the outcome of movements and efforts within its predecessor, the Federal Center of Technological Education of Paraná (CEFET-PR), to respond to the deconstruction of the technical education model, on which the Institution was based, during the Fernando Henrique Cardoso government. The concept of a technological university has not been replicated in any government since the transformation of CEFETPR to UTFPR, not even during the Workers' Party (PT) government, which introduced the model. We conclude that, despite efforts from within, the legal apparatus and the pursuit of certain characteristics and goals, such as obtaining world class status, are aligning UTFPR increasingly toward the profile of traditional universities.
\end{abstract}

Keywords: Technological University; Federal University of Technology - Paraná; education policy; technical education.

\section{Introduction}

Universities are places of knowledge and science, although they do not hold a monopoly on these concepts. In Brazil, the idea of the university is based on the inseparable triad of teaching, research, and extension, as outlined in Article 207 of the 1988 Constitution: "universities benefit from autonomy in didactic-scientific, administrative, financial, and patrimonial management and will observe the principle of the inseparability of teaching, research, and extension" (Brasil, 2016, p. 123).

Among developing countries, the academic and technological infrastructure of Brazil since the 1950s has been unique, mainly due to initiatives of the federal and some state governments (Brito Cruz, 2010). Some of the initiatives that have helped position Brazil at this important level include its public universities, the National Council for Scientific and Technological Development (Conselho Nacional de Desenvolvimento Científico e Tecnológico; CNPq), the Coordination for the Improvement of Higher Education Personnel (Coordenação de Aperfeiçoamento de Pessoal de Nível Superior; CAPES) (Chiarini \& Vieira, 2012) and exceptional public companies such as Embraer, Petrobrás, and Embrapa (Schneider, 2015). 
Universities develop the foundational understanding that not only pushes the boundaries of the social underpinnings of knowledge, but also employs and expands on this knowledge. This creates the mistaken perception that the role of the university is to solve current problems (Brito Cruz, 2010). Yet, the sole mission of the university is to advance knowledge alongside education.

University research differs from research in the private sector, as it is linked to education that provides stimulus for learning and critical thinking and is based on the scientific method. Academic research can be obscure, and its usefulness or functionality does not necessarily have to be immediately evident, which includes the exploration of basic science. In the private sector, research serves to improve products or internal processes. It is essentially applied research, offering a space for the development of excellence in technology (Brito Cruz, 2010).

According to Brito Cruz (2010), academic freedom and autonomy are essential principles for universities to maintain their vitality. Despite its importance, academic freedom is poorly understood, and its misinterpretation originates from the utilitarian assumptions of that underly discussions about science and technology in Brazil. There are two main sides of utilitarianism. In conservative utilitarianism, which has an economic focus, the main function of universities is to support the productive sector. On the other hand, leftist utilitarianism has a more a social focus, in which the role of universities is to support actions directed at poverty reduction and creating healthier and more equitable societies.

Although it is desirable that universities contribute economically and socially, both of which are primordial to the country, neither role is part of a university's raison d'être (Brito Cruz, 2010). The main purpose of the university is to train people to use knowledge, thus enabling them to develop solutions or mitigate problems both in industry and society. As such, the university helps companies to become more competitive, while also supporting the formulation of public policies for the betterment of Brazil. Universities cannot act as Ministries of Health, Education, or Economy, or even as the center of research and development for a company. The virtue of its relationship with the outside world lies in the association of the advancement of knowledge with education.

Among these intricacies and considering that the role of the university is increasingly complex and sophisticated (Santos, Nascimento \& Buarque, 2015), herein the concept of the technological university (TU) in Brazil will be examined. The investigation will explore historic and contemporary experiences around the world, and then consider the development of TUs in Brazil, particularly the Federal University of Technology - Paraná (UTFPR), the only TU in the country. Unlike traditional universities, TUs and technological institutions are based on a wide range of distinct models. In part, this diversity is the result of legislation in the countries where the technological institutions are located.

Although the name TU is widely used in the literature, few studies offer an in-depth analysis of the conceptual issues. Of the studies that examine TUs from a conceptual perspective, most focus on the institutional and national context in which the institutions are established (Cunnane, 2018; Doern, 2008; Du Pré, 2010; Harkin e Hazelkorn, 2015; Hatton, 2002; Hayhoe, 1989; Houghton, 2020; Kyvik, 2002; Laya, 2009; Lewis, 1991; Lievore, Pilatti e Teixeira, 2021a; McKenna e Sutherland, 2006; Mildred, 2002; Norgård e Skodvin, 2002; Pratt, 1997).

In Brazil, despite UTFPR being unique in the country, the few studies that have examined the concept mostly remain within the scope of the institution itself (Cechin, 2019; Costa et al., 2019; Helmann, 2019; Lievore \& Pilatti, 2018; Lievore, Pilatti \& Teixeira, 2021a; Lievore, Pilatti \& Teixeira, 2021b; Pilatti \& Lievore, 2018b; Pilatti, 2017).

Mainly through the analysis of official documents, this study examines the historical trajectory of TUs, and discusses the construction and deconstruction of the TU model in Brazil. Because only one TU exists in the country, the focus of the study is inherently directed at UTFPR. Through our documentary analysis, it becomes clear that official documents shape reality, but they cannot be read as unilateral constructions. This disjuncture stems from the fact that documents are products of a certain socio-historical context and permeated with contemporary discourse.

\section{Technological Universities (Institutions)}

2.1 Trajectory, concept, and framework of technological universities (institutions) in the world 
Unlike traditional universities, which have an almost a thousand-year history, TUs are a more recent phenomenon. The first TUs emerged in Europe in the eighteenth century during the Industrial Revolution. In this period, the following institutions were founded: Czech Technical University in Prague, Czech Republic, in 1707; Technical University of Berlin, in Germany, in 1770; Istanbul Technical University, in Turkey, in 1773; Budapest University of Technology and Economics, in Hungary, in 1782; École Polytechnique, in Paris, France, in 1794; and the University of Strathclyde in Glasgow, Scotland, in 1796 (Pilatti \& Lievore, 2018a). In the United States, several technological institutions were established in the second half of the nineteenth and early twentieth century. The spread of the model to Asia occurred mainly after World War II.

Despite the fact that they emerged during the industrial revolution, Pilatti and Lievore (2018b) argue that TUs were not necessarily a demand of the epoch. To support such an argument, they point out that 100 years after the beginning of the first industrial revolution, there were 25 technological universities in 19 countries on two continents, Europe and Asia. It took more than 200 years to reach a total of 50 technological universities worldwide.

Technological institutions, such as colleges or universities of applied sciences, technical universities, polytechnic institutes, among others, appeared basically through two avenues: they were created with a predominant focus on the areas of engineering and technology; or resulted from the transformation or agglomeration of institutions working in technical and vocational education (Lievore \& Pilatti, 2018).

Depending on the educational characteristics of the nations in which they are located, the terminology used for TUs is applied in a variety of ways. This is mainly due to imprecision around the concept of the TU (Lievore \& Pilatti, 2018; Mckenna \& Sutherland, 2006).

The interaction and integration of two essentially opposing concepts, university and technology, to some extent creates the contradictory concept of TUs. The idea of university comes from the Latin universitas, which means universality, totality. The concept of technology is of Greek origin and formed by the junction of tekne, which means art, technique, craft, with logos, which means set of knowledge.

From the nineteenth century, TUs spread around the world. Despite their common features, the characteristics of this type of institution depend to significant degree on geographical location (Lievore \& Pilatti, 2018). A central feature, produced through the inherent opposition of the concept, is linked to the idea of specialization.

As an ideal within a Weberian perspective, specialization can be represented as two extremes: as a means (broad) or as an end (strict). Following this representation, institutions are situated along a continuum between two extreme poles, potentially leaning more towards one or the other. In reality, it is unlikely that any institution employs the concept of specialization fully as a means or as an end.

As a means, specialization, which is closely linked to the idea of technology in the concept of TU, is linked to the institutional interests that ideally go beyond areas of knowledge. In fact, a TU that sees technology as a means comes close to the idea of universitas. Thus, technology loses the connotation of an end goal and becomes a means within the curriculum, employed in a multidisciplinary way in all areas of knowledge. The idea of technology as an end, in its ideal form, is associated with a transdisciplinary model. Thus, specialization indicates a fundamental focus on the areas of engineering and technology.

Within the Latin American context, the Network of Technological and Polytechnic Universities of Latin America and the Caribbean (Red de Universidades Tecnológicas y Politécnicas da América Latina y el Caribe; RUTyP), chose five strategic axes to define a model that represents TUs and similar institutions around the world. The main characteristics are: innovation and entrepreneurship; research, development, and technology transfer; technology parks and knowledge cities; social and environmental responsibility; and connection with the productive sector (Pilatti \& Lievore, 2018a; Red de Universidades Tecnológicas y Politécnicas da América Latina y el Caribe, 2017).

Du Pré (2010), in analyzing South African higher education (HE) technology institutions, identified the overall characteristics of the TU model as:

a) excellence in teaching and learning;

b) applied research; 
c) developing leadership in technology;

d) technology transfer and innovation;

e) partnership with industry (education for the world of work);

f) internationalization (for benchmarking good and best practices).

In the UK, Lewis (1992) argues that despite being part of a diverse group of institutions and having a distinct ethos and objectives, polytechnics have many similarities with universities. In defining the differences, Lewis (1992) highlights the danger of looking for differences that may be more imaginary than real and resorting to convenient generalizations. However, for the author, the common features that characterize the mission of polytechnics are:

a) education is the main role;

b) access for the underprivileged and marginally represented in society is paramount;

c) aptitude for higher education is a more important criterion for admission than formal admission requirements;

d) strong link with local and regional communities, with the productive sector, and public services;

e) the subjects and programs are closely related to the world of work;

f) importance is given to the validation and monitoring of academic standards;

g) part-time students constitute a large proportion of enrollments;

h) a substantial proportion of enrollments are in undergraduate programs, rather than graduate programs.

For Lievore and Pilatti (2018), it is in the symbiosis between teaching, applied research, and technology transfer, in addition to proximity to the productive sector, that the TU model is generally designed around the world. This model is consistent with the context in France. Despite the lack of a widely accepted concept, such as that of traditional universities, the authors identified characteristics that distinguish TUs:
a) more practical technological teaching;
b) prevalent performance in engineering and technology courses;
c) applied research focused on solving problems arising from industry;
d) production and transfer of technology;
e) strong links with the productive sector;
f) emphasis on innovation and entrepreneurship;
g) production and use of technology for local and regional development;
h) faculty with experience in the productive sector;
i) training of knowledge workers.

The actual materialization of TUs is multidimensional and occurs in different ways. Variables that affect the process include the educational policies of the country, often determined by the political regime in the form of legal frameworks, and the issue of when the institution was conceptualized.

In terms of temporality, an important impetus arose from the movement known as May 1968; a movement with Paris as its epicenter that spread to several other countries. The precursor of the movement was marked by a wave of demonstrations by students and workers who demanded better physical and didactic conditions for universities and the expansion of the French university system. From this movement, the French university system was remodeled under Law no. 68-978 and, in 1972, the first university of technology in France was created, the University of Technology of Compiègne (Université de Technologie de Compiègne) (Cechin, Pilatti \& Ramond, 2021). As a result of the movement, which reached a global scale, many 
technological institutions were created or transformed in the 1970s. Following May 1968, two main phenomena related to TUs occurred worldwide, one of expansion and the other of redesign.

The first notable movement is the significant increase in the number of TUs that were created or transformed. The phenomenon spread beyond Europe, Asia, and the United States, where most technological institutions had been restricted, to subsequently conquer the globe, with a few exceptions (Hayhoe, 1989). The experience of TUs in Mexico is an important example in this context. In the early 1990s, the government created TUs to offer two-year programs to secondary school graduates. The programs granted a degree of trained technician with a university education (Laya, 2009).

The second movement is underway and consists of the redesign of TUs. The convergence point of this movement is in the approximation or unification of the statutes that distinguish traditional institutions from technological ones, mainly in terms of their core competencies.

In several countries, part of this redesign has been the accreditation of technological institutions to grant academic degrees and doctoral diplomas. The process is already in place in countries such as Germany, Holland, Switzerland, Turkey, and Taiwan. In Portugal, despite already having legislation in place, the process has not yet been implemented nor has it been peaceful as it involves institutional and political interests (Lievore, Pilatti \& Teixeira, 2021a, 2021b).

In the UK, the two-tier system of HE formed by universities (research-oriented) and polytechnics (bringing together engineering and applied sciences with a practical professional focus) was overcome in 1992 with the designation of polytechnics as universities, allowing them to issue their own diplomas. A process with some similarity to that in the UK is underway in Ireland and is perhaps one of the most important ongoing examples, along with the integration of the University of Technology of Compiègne into the Sorbonne in France in 2018 (Cechin, 2019).

In Ireland, on January 1, 2019, the first TU, Technological University Dublin, was established. This institution, which is the second largest in the country and has a history dating from 1887, is the result of the merger of three institutes of technology: the Dublin Institute of Technology; the Institute of Technology, Tallaght; and the Institute of Technology, Blanchardstown. Two other TUs, resulting from the merger of institutes of technology, are also being established: the Munster Technological University and the Technological University of the South East (Houghton, 2020).

This transformation is the result of a strategy within Irish HE, in which TUs are formed by the merger of technological institutes and focus on preparing students for complex professional roles in a changing technological world. The role of the professional trained by TUs is to disseminate knowledge in a way that meets the needs of society and business, with special attention to the needs of the region in which the university is located (Process and criteria for designation as a technological university, 2021).

Houghton (2020), examining the 11 remaining technology institutes in Ireland to understand the implications of transformation by amalgamation, discussed a similar strategy put in place in the UK in 1992. It is worth noting that other countries, such as Australia (Hatton, 2002; Mildred, 2002) and Norway (Kyvik, 2002; Norgård \& Skodvin, 2002); have experienced comparable amalgamation processes. In the study, Houghton(2020) classifies the process as a fundamental fracture between Irish polytechnics and universities. The practical effect of the process was a race to build coalitions and the ultimate prize was obtaining TU status (Harkin \& Hazelkorn, 2015).

Houghton's (2020) starting point is the experience of Ireland's closest neighbor, the UK, which had a similar two-tier system and transformed its polytechnics into universities. For Pratt (1997), the fact that the polytechnics called themselves universities concealed the fact that these universities became polytechnics. The experience is referred to as vocational drift (Doern, 2008).

For Houghton (2020) there is a real threat of loss of vocation for polytechnic institutes with their transformation into universities. Cunnane (2018) warns that, through the transformation process, the new institutions will present themselves with a capital $\mathbf{U}$ and a lowercase $\mathbf{t}$ to compete in world rankings. The quest for inclusion in world rankings presupposes a movement toward criteria different from those that Irish polytechnics have always adhered to in order to effectively serve their communities (Cunnane, 2018). 
In the UK, in becoming TUs, polytechnics lost much of their vocational orientation and became victims of vocational drift, seeking to emulate traditional universities in terms of disciplines and focus (Houghton, 2020). In some cases, the transformed universities have become rather pale imitations of this type of institution, lacking a coherent philosophy and purpose.

By way of comparison, Houghton (2020) sees an important and unfortunate distinction between what is happening in Ireland and what has occurred in the UK. In the UK, the transformed polytechnics have adopted the nomenclature of university. In Ireland, as has occurred in other European countries such as the Netherlands and Finland, there is a requirement to retain the TU nomenclature for polytechnics that become universities. In effect, in a system without differentiation, a distinct cluster of HE institutions may be created in terms of status, which may reproduce the existing two-tier system (Houghton, 2020).

In Houghton's (2020) view, using the name university is necessary to overcome the inadequate and outdated second-class status that is often assigned to polytechnic institutes. Compared to universities, although the student body of polytechnic institutes is made up of students from across the social spectrum, they disproportionately serve the less advantaged (Higher Education Authority, 2019). Nevertheless, Houghton (2020) sees that with TU status, institutes can break free from their inferior status.

According to Houghton (2020), other prospective problems in the ongoing Irish process include:

a) conflicts arising from complex merger processes;

b) the spatial distance between merged institutions and the possible dismantling of the cluster policy and regionalism underway in Irish HE;

c) the development of a research culture in the new TUs that moves away from careers focused on teaching with no incentives for research to a culture of meritocracy;

d) difficulty of rationalizing the system with mergers;

e) the construction of a new organizational culture and identity with the inclusion of "new blood' or recent recruits in the organization;

f) political disputes over leadership positions.

In this complex and uncertain scenario, Houghton (2020) questions what will be lost in the transition to TU status, revealing concerns about maintaining a focus on the local and regional and the distinctive mission of the new institution. These concerns are aligned with Cunnane's (2018) fear of the development of tU (with a lowercase t) or simply universities.

\subsection{From trade and apprenticeship schools to the Federal University of Technology - Paraná (UTFPR)}

In Brazil, the technological institutions that have endured, in most cases with a range of different names and scopes than their current iteration, followed two main paths, first military and then public. In the private sector there are no significant long-term examples of technological institutions.

In the military context, specifically in the Navy, the Naval School is the first long-term HE initiative with a technological focus in the federal system that has maintained its specialized characteristics until its current format. Located in Rio de Janeiro since 1808, the Naval School was founded in 1782 with the name of Royal Academy of Marine Guards (Academia Real de Guardas-Marinha), and later renamed Naval School (Escola Naval) in 1886 (Marinha do Brasil, 2021). In 2020, the Naval School offered 22 admission places for training officers.

Considered an example of excellence on the national scene, the Technological Institute of Aeronautics (Instituto Tecnológico de Aeronáutica; ITA) was created by Alberto Santos-Dumont in the 1910s (Dumont, 1918). Inspired by the Massachusetts Institute of Technology (MIT), ITA was founded in São José dos Campos in 1950. The first course offered at the institution was Aeronautics Engineering (Instituto Tecnológico de Aeronáutica, 2021). After developing the nucleus that gave rise to Embraer, ITA has become a reference as a model for teaching and integrating research and industry partnerships (Forjaz, 2005). In 2021, 150 admission places were offered at ITA, with 31 for those intending to continue as an officer of the Brazilian Air Force and 119 for those intending to pursue a civil career after graduation. 
Another important reference in the military context is the Military Engineering Institute (Instituto Militar de Engenharia; IME). Like the Naval School, the history of the IME dates to 1792, during the colonial period in Brazil, with the founding of the Royal Academy (Real Academia) in Rio de Janeiro, the first in the Americas and third in the world. After several name changes, in 1858 the institution was transformed into the Central School (Escola Central). In addition to training officers, the Central School also trained military and civil engineers, and was the only engineering school in Brazil at the time. Subsequently in 1874, due to influence of the Germans, the Central School left the military sphere, and transferred its activities exclusively to the training of civil engineers within the scope of the Secretariat of the Empire (Instituto Militar de Engenharia, 2021).

More than five decades after the demilitarization of the Central School, the Military Engineering School (Escola de Engenharia Militar) was founded in 1930, inspired by the French military mission. It received a new name in 1933, becoming the Technical School of the Army (Escola Técnica do Exército). Later, in 1949, and influenced by the Americans, the Military Institute of Technology (Instituto Militar de Tecnologia) was created. Ten years later, the two schools were merged into the IME, and in 1964, the IME started admitting civilians (Instituto Militar de Engenharia, 2021). During the 2020/2021 entrance exams, IME offered 98 admission places, of which 70 were for active-duty officers and 28 for reserve officers.

Together, the HE institutions of the Brazilian Armed Forces admit around 270 students per year. In a country the size of Brazil, this number is insignificant, and, despite their recognized excellence, these institutions are of little importance in the Brazilian educational context. Despite the similarity between military institutions of HE in Brazil with existing institutions in other countries, we can see that the idea of the TU under construction in Brazil did not follow the military path.

In the civilian context, the initial milestone was Decree No. 7.566 (Brasil, 1909). With this Decree, Trade and Apprenticeship Schools (Escolas de Aprendizes Artífices) were created in each of the state capitals by the president at the time, Nilo Peçanha. With the federal government as patron, and a focus on free basic professional education, the schools were intended for the less advantaged in society, referred to in many documents as the unfortunate, and aimed to train workers and foremen (Brasil, 1909). According to Cunha (2000), their establishment represents one of the first positivist initiatives in the republican regime to train the labor force, particularly in terms of manufacturing.

At the time, Brazil was divided into 20 states and the Federal District. Even though Decree No. 7.566 (Brasil, 1909) mentioned all state capitals, no school was established in Rio Grande do Sul State, nor in the Federal District (Brasil, 1912). In 1919, the number of institutions expanded with the incorporation of the Wenceslau Braz School of Arts and Crafts (Escola Normal de Artes e Ofícios Wenceslau Braz), located in the Federal District.

Under Law No. 378 (Brasil, 1937), and before the implementation of the New State (Estado Novo), the schools maintained by the federal government were transformed into secondary schools. Under this law, secondary schools that offered basic education, were refocused toward professional training in all fields and at all levels (Brasil, 1937). The wider scope of the schools created in 1909 is related to the intervention by the State in the economy, which sought to achieve progress through the rapid industrialization of the country. This economic policy intended to transform Brazil's natural vocation to a specialization in primary goods exportation and sought to break away from the liberal dogma of self-regulated markets (Amorim, 2013).

Through Law No. 378 (Brasil, 1937), the Ministry of Education and Public Health was reorganized, and Article 34 states that "The University of Rio de Janeiro and the Federal Technical University will join to form the University of Brazil". This amalgamation had been planned since 1931, with the signature of Minister Francisco Campos, in a decree that advocated for the university system to be constructed through the amalgamation of isolated HE schools (FGV CPDOC, 2021). The University of Brazil, which became the Federal University of Rio de Janeiro (Universidade Federal do Rio de Janeiro-UFRJ) in 1965, was born through the merger of 15 schools or faculties, all of which received national denomination, with 16 institutes, some of which had not yet been created, and the National Museum (Brasil, 1937; FGV CPDOC, 2021). 
The Federal Technical University (Universidade Technica Federal), which was part of the University of Brazil, is almost a blank page in the historiography of Brazilian education. One of the few passages available in the literature that indirectly cites the Federal Technical University, is in the 1957 Yearbook of the National School of Chemistry (Escola Nacional de Química). It states that the School, which was created on July 28, 1933, "On July 14, 1934, by Decree No. 24.738, was transferred to the Ministry of Education at the time, and incorporating the Federal Technical University" (Universidade do Brasil, 1958, p. 1). From this excerpt we can deduce that the Federal Technical University was the result of the merger of a set of schools or colleges organized in the form of a policy established by Francisco Campos, which was an ephemeral initiative.

In 1942, the Statue of Industrial Education, Decree-Law No. 4.073 (Brasil, 1942b), created the conditions for a new transformation, which was implemented a few days later with Decree-Law No. 4.127(Brasil, 1942a). This decree defined the federal network of industrial teaching establishments, consisting of technical, industrial, trade, and apprenticeship schools, and transformed the secondary schools created in 1937. The Decree-Law created 11 federal technical schools and 13 federal industrial schools, that would provide professional training in two phases of industrial education, and enabled the possibility for graduates of the secondary school level of industrial education to access the higher level in related fields.

According to Cunha (2000), the creation of technical and industrial schools at the federal level and during the Vargas Era, reinforced the progressive ideology of industrialism. The proclaimed values of industrialism included progress, economic emancipation, political independence, democracy, and civilization, among others. Through industry, the project sought to elevate Brazil to the level of civilized nations, such as the United States and countries in Europe. From the perspective of the industrialists, professional education was also a powerful instrument to solve social problems (Cunha, 2000). During their 33-year tenure, approximately 141.000 students passed through the Secondary Schools and Schools of Trade and Apprenticeship (Cunha, 2000).

In 1956, Juscelino Kubitschek de Oliveira became President of Brazil (Cunha, 2002). The situation created by Getúlio Vargas' suicide, and the ensuing political and economic crises, was quite complex. Juscelino took power with the implementation of his developmental action plan called "Fifty Years in Five", in which the goal was to align the Brazilian economy with the American. In the realm of education, key adjustments to the ongoing policy and adaptation of the 1946 Constitution included Law No. 3.552 (Brasil, 1959b) and Decree No. 47.038 (Brasil, 1959a). The law established a new organizational and administrative structure of the industrial teaching establishments in the Ministry of Education and Culture (Brasil, 1959b). The decree regulated industrial education, allocating it to the level of secondary school and indicating that the federal schools of the Ministry of Education and Culture should follow the legislation (Brasil, 1959a). As a result of the decree, the schools within its purview once again changed their names.

During Brazil's military dictatorship, under Decree-Law no. 547 (Brasil, 1969), the Federal Technical Schools of Paraná, Rio de Janeiro, and Minas Gerais were authorized to offer short-term HE courses. With this legal authorization and the implementation of Operation Engineering Centers with resources from a partnership with the International Bank for Reconstruction and Development (BIRD), the three technical schools began to offer short-term HE courses at the beginning of the following decade (Helmann, 2019).

With this authorization, the three institutions gained a new profile. According to Guimarães (2002), the specific characteristics of the model were:

a) exclusive focus on the area of technology;

b) higher education as a continuity of technical secondary school education, differentiated from the university system;

c) emphasis on specialized training aimed at the labor market and development;

d) focus on applied research and providing services to the community.

The Directives and Foundation Law of 1971 highlighted education and compulsory professionalization (Giorgi \& Almeida, 2014). But the overall movement began to gain real ground with the transformation of the three federal technical schools into Federal Centers for Technological Education (Centros Federais de Educação Tecnológica; CEFETs), including CEFET Paraná (CEFET-PR), Minas Gerais (CEFET-MG) and 
Rio de Janeiro (CEFET Celso Suckow da Fonseca - CEFET-RJ), with authorization to act in the realm of HE (Brasil, 1978). With the creation of the CEFETs, the new iteration of these institutions implemented fullterm HE courses in the areas of Industrial Engineering and training courses for technicians (Guimarães, 2002; Pilatti, 2017). The features of the new model were outlined in the objectives in Art. 2 of Law No. 6.545 (Brasil, 1978):

I - to provide higher education:

a) undergraduate and graduate, aimed at the training of professionals in industrial engineering and technicians;

b) full and short-term licentiate degrees, aiming at the education of teachers and specialists for the disciplines of secondary school education and courses for the education of technicians;

II - to provide secondary school education for the training of industrial assistants and technicians;

III - to promote extension, improvement, and specialization courses, aiming at professional upgrading in the industrial technical area;

IV - to carry out research in the technical industrial area, stimulating creative activities and extending its benefits to the community by means of courses and services.

These directives were partially changed with Decree No. 87.310 (Brasil, 1982), which regulated the 1978 Law. The main changes introduced were:

a) the integration of secondary school technical education with higher education;

b) higher education as a continuity of secondary school technical education, differentiated from the university education system;

c) emphasis on specialized training, considering the labor market and development trends;

d) acting exclusively in the technological area;

e) conducting applied research and rendering services.

The system remained stable until 1986, at which point the José Sarney government instituted a program to expand the CEFETs beyond the state capitals. In practical terms, the CEFETs created decentralized units throughout the rural interior of their respective states. In 1988, the Citizen Constitution was enacted. In 1989, the Technical School of Maranhão, in President Sarney's home state, was transformed into CEFET Maranhão (CEFET-MA) through Law No. 7.863 (Brasil, 1989), a political maneuver that disregarded the technical criteria and occurred in isolation.

In 1993, in accordance with Law No. 8.711 (Brasil, 1993b), and with Itamar Franco as president, the Technical School of Bahia was transformed into CEFET Bahia (CEFET-BA). The following year, under Law No. 8.948 (Brasil, 1994), the National System of Technological Education was created. The system was made up of the five existing CEFETs, the Federal Technical Schools created in 1959, and the Federal Technical and Agrotechnical Schools (Escolas Técnicas e Agrotécnicas Federais) created by Law No. 8.670 (Brasil, 1993a). The establishment of the new CEFETs occurred gradually, by specific decree for each center.

With Fernando Henrique Cardoso (FHC) in power, Brazil began to have a more clear educational policy that went beyond isolated initiatives. The policy put in place while FHC led the country was a neoliberal one, and the process of privatization of $\mathrm{HE}$ is an important element of the model. Universities experienced significant challenges, with the stagnation of salaries and budgets, in addition to a process of attrition in which staff were not replaced when they left (Cunha, 2003). The guiding principle of the FHC government in terms of education was that the resources available were sufficient if their use was optimized (Pinto, 2002). 
On December 20, 1996, HFC enacted Law no. 9.394 (Brasil, 2005a), the Law of Directives and Foundations of National Education (LDB). In the law, and specifically in the sole paragraph of Art. 52, the possibility of creating specialized universities by field of knowledge was indicated (Brasil, 2017). Many aspects of the LDB required regulation, and this regulation came in the form of Decree No. 2.208 (Brasil, 1997), which significantly affected the National System of Technological Education. By excluding the possibility of providing technical education integrated with secondary school education, Article 5 of that decree dismantled the model in which approximately $70 \%$ of the students in CEFETs were enrolled (Pilatti, 2017). The wording of Article 5 is: "Technical level professional education will have its own curricular organization and be independent of secondary school and may be offered concomitantly or sequentially to it" (Brasil, 1997).

In the second half of the 1990s, looking to insert itself in the ongoing expansionist policy which was aimed at meeting the training demands of professionals in the technological area and based on the new LDB, the Federal Engineering School of Itajubá (Escola Federal de Engenharia de Itajubá), created in 1913, began to claim the status of a specialized technological university (Universidade Federal de Itajubá, 2021). This was the first project for a TU in Brazil. In 1998, the project gained some ground with the increase from two to nine new undergraduate courses at the institution (Universidade Federal de Itajubá, 2021).

On April 24, 2002, the project to transform the Federal School of Engineering of Itajubá into a university was sanctioned by President FHC, thus creating the Federal University of Itajubá (Universidade Federal de Itajubá; UNIFEI). Regardless of the original project and despite keeping its focus on engineering courses, UNIFEI abandoned its initially claimed condition of a specialized university in its name (Universidade Federal de Itajubá, 2021). The exclusion of UNIFEI in the Federal Network of Professional, Scientific and Technological Education (Brasil, 2008) clearly shows that in the eyes of the Ministry of Education (MEC) the institution was not transformed into a specialized university.

Concomitantly, with the National System of Technological Education being systematically expanded, Decree No. 5.224 (Brasil, 2004) established a new organizational model for CEFETs. For the first time, the decree makes clear mention of the scope of technological education as the purpose of CEFETs. In Art. 3. (Brasil, 2004), the basic characteristics of CEFETs are described:

I - Offer technological education, considering the advancement of technological knowledge and the growing incorporation of new methods and processes of production and distribution of goods and services;

II - priority action in the technological area, in various sectors of the economy;

III - integration of theory and practice in teaching;

IV - vertical articulation and integration of technological education with the different levels and modalities of education, with work, science, and technology;

$\mathrm{V}$ - offer undergraduate and graduate higher education in the technological area;

$\mathrm{VI}$ - offer specialized training at all levels of education, taking into consideration the trends of the productive sector and technological development;

VII - conducting applied research and providing services;

VIII - developing teaching practice, encompassing the different levels and modalities of education, considering the qualifications required in each case;

IX - shared use of laboratories and human resources across different levels and modes of education;

$\mathrm{X}$ - developing an educational process that permanently favors the transformation of knowledge into goods and services for the benefit of society;

XI - organizational structure that is flexible, rational, and appropriate to its peculiarities and objectives; 
XII - integration of educational actions with society's expectations and trends in the productive sector.

The following year, under Law No. 11.184 (Brasil, 2005b), the first and the only TU in Brazil was created, UTFPR. As a transformation from CEFET-PR, the university is the result of an internal institutional project that found resonance in the expansionist policy of federal public HE carried out by then President Luiz Inácio Lula da Silva (Lula) (Pilatti, 2017).

2.3 What is a technological university in Brazil?

To answer the question 'what is a TU in Brazil?' in a consistent and accurate way, it is necessary to take a closer look at UTFPR, as it is the only successful TU initiative in the country to date.

UTFPR went through the process of transformation during a period in which a new kind of university was being envisaged for Brazil within the Lula government. However, for the first time, and unlike the transformations experienced by the institution since its original iteration as the School of Apprentices and Artificers (Escola de Aprendizes Artífices), the process grew from within the institution, and was not part of an educational policy.

The process of transformation into a specialized university was supported by the LDB of 1996, and was silently triggered by Decree No. 2.208 (Brasil, 1997). Until this decree, the National System of Technological Education had been stable. And in this system, the CEFETs created in 1978 were considered a reference of quality in the formation of technical labor (Guimarães, 2002). However, with the dismantling brought about by Decree No. 2.208 (Brasil, 1997), CEFET-PR became the protagonist in the construction of a new design for the system.

The path taken by CEFET-PR was to substitute technical courses with HE technology courses. The option, permitted by the LDB, represented the resumption of a model that had failed in the 1970s, and had been used mainly by private institutions to leverage these courses and enter the realm of HE. When the modality was adopted, internally there was little clarity about what technology courses were or their applicability (Pilatti, 2017). Internally, there was the idea that the technical courses to be replaced already met the requirements of HE (Guimarães, 2002).

In 1997, CEFET-PR had its headquarters in the city of Curitiba, with five decentralized units (UNEDs) located in the cities of Campo Mourão, Cornélio Procópio, Medianeira, Pato Branco, and Ponta Grossa. At the headquarters, undergraduate and graduate courses were offered alongside technical courses. In the UNEDs, only technical courses were offered. After the decree, HE technology courses began to be offered in all CEFET-PR campuses, while secondary school courses continued to be offered but a reduced scale (Guimarães, 2002).

Displacement of the area of focus from the secondary school to the HE level gave birth within CEFET-PR to the idea of transforming the institution into a specialized university (Guimarães, 2002). In 1999, the proposal to create a specialized university was approved by the highest body of the institution. Besides the possibility opened up by the LDB, the request was based on CEFET-PR's academic indicators that met the legal requirements in effect to obtain university status. Within the National System of Technological Education, only CEFET-PR had achieved these academic indicators. However, the proposal was immediately rejected by the then Minister of Education, Paulo Renato Souza (Pilatti, 2017).

With the rise of Lula to the presidency, CEFET-PR found in the Minister of Education Cristovam Buarque an ally of the proposed transformation. Through a process that was supported internally, the proposal was transformed into a bill and submitted to the Chamber of Deputies and the Senate (Pilatti, 2017). The bill was very similar to Law No. 6.545 (Brasil, 1978). After minor adjustments and approval in all instances, the bill was sanctioned by President Lula, in October 2005, through Law No. 11.184 (Brasil, 2005b).

Within the structure of MEC, although transformed, UTFPR remained within the Secretariat of Technological Education (Secretaria de Educação Tecnológica; SETEC), along with the other CEFETs, unlike universities which are designated to the Secretary of Higher Education (Secretaria de Ensino Superior; SESU). While the transformation was celebrated throughout the system, at the same time it had important implications. 
With the transformation that occurred in Paraná, many CEFETs used political means to plead for the rank of TU (Pilatti, 2017), a movement that had the most strength in the CEFETs of Rio de Janeiro and Minas Gerais. These institutions, although not reaching the indicators required by the current legislation, presented indicators and scope similar to those of Paraná.

Despite the reversal of Decree No. 2.208 (Brasil, 1997), the autonomy of the university enabled a shift in focus in UTFPR, which was already at a high level, beyond HE courses of technology, in opposition to the educational policies determined by MEC.

The conflict was managed with through two main measures within the Lula government, the movement of UTFPR to SESU and the transformation of the remaining CEFETs into Federal Institutes of Education, Science, and Technology (Institutos Federais de Educação, Ciência e Tecnologia; IFs) (Brasil, 2008). We can consider that, in an attempt to avoid a dismantling of the federal system focused on secondary school technical education, MEC effectively demobilized efforts to transform CEFETs with Decree 6.905 (Brasil, 2007). Only CEFET-MG and CEFET-RJ did not adhere to the decree and, as such, did not become IFs. These two institutions continued to seek the rank of TU and the subsequent modifications to their model (Ciavatta, 2006).

On December 29, 2008, President Lula sanctioned Law number 11.892 (Brasil, 2008), which established the Federal Network of Professional, Scientific, and Technological Education within the federal education system and linked to MEC, creating 38 IFs. These 38 IFs, UTFPR, CEFET-MG, CEFET-RJ, and the Technical Schools connected with Federal Universities were included in the Network. In 2012, Pedro II College, in Rio de Janeiro, was also incorporated.

After several changes in government, the demands of CEFET-MG and CEFET-RJ have not yet been met. Since Lula's presidency, it is evident that subsequent governments have taken a position against the creation of other TUs, at times imposing measures on these CEFETs that can be seen as coercive to force their transformation into Ifs (Pilatti, 2017).

With the transformation of UTFPR into a university in 2008, the institution was able to join the Support Program for Restructuring and Expansion Plans of Federal Universities (Programa de Apoio a Planos de Reestruturação e Expansão das Universidades Federais; Reuni). The inclusion of UTFPR was one of the final initiatives carried out in the program, and despite criticisms of the program, the process was peaceful, unlike the situation at some federal universities (Pilatti, 2017). Criticisms of the program highlight the continued dismantling of the scientific-technological model, as occurred in the neoliberal policy of FHC's government and imposed by international financial organizations on Latin America (Borges \& Aquino, 2012; Léda \& Mancebo, 2009).

After a long period of staff stagnation and attrition, Reuni helped UTFPR to continue the process of expanding into rural areas of the state and increase the number of course offerings, particularly in engineering.

With this expansion, the profile of the teaching staff became more academic, in accordance with the legislation that began to require a doctoral degree for professors in public federal universities. However, proximity to the productive sector, which was a key feature of CEFET-PR and is characteristic of TUs, to a certain extent is being lost (Pilatti, 2017).

After the completion of the Reuni Program, UTFPR became of one of the ten largest federal universities in Brazil (in terms of budget, number of students, number of student equivalents, number of professors, and admission places offered, among other indicators). The institution, with campuses located in 13 cities across the State of Paraná, has the largest number of satellite campuses of all Brazilian federal universities. Approximately $70 \%$ of UTFPR's students are enrolled in campuses located in rural communities and small cities outside the capital. Thus, UTFPR is also the most active federal university in rural Brazil.

After joining the Reuni Program, UTFPR focused its activities on engineering courses, which are now offered at campuses throughout the state. Currently, the institution offers the largest number of engineering student admissions in Brazil among federal universities. However, with the movement towards engineering, the dissolution of technical and technology courses has also occurred. The inclusion of graduate studies was 
another major step taken with the restructuring. A little more than a decade after joining Reuni, UTFPR went from offering five to more than 50 courses.

To some extent, the present profile of the institution, as the result of developments within MEC and internally, point to a shift from the structuring principles proposed in the Law that created UTFPR. The design of the first TU in Brazil is outlined in four articles of Law No. 11.184 (Brasil, 2005b) with Article 2 defining the principles:

I - emphasis on the formation of human resources, within the scope of technological education, in the different levels and modalities of education, for the various sectors of the economy, involved in technological practices and in the experience with the actual problems of society, focused, notably, on local and regional socioeconomic development;

II - valuing leadership, stimulating social promotion and the formation of citizens with a critical and entrepreneurial spirit;

III - maintaining close ties with technology, aimed at the construction of citizenship, democracy, and an active life of creation and production in solidarity;

IV - development of a culture that stimulates the functions of thinking and doing, associated with teaching, research, and extension;

$\mathrm{V}$ - integration of the generation, dissemination, and utilization of knowledge to stimulate local and regional socioeconomic development;

VI - approximation of scientific and technological advances with the citizen-laborer, to face the socioeconomic reality in which he/she lives;

VII - decentralized organization through the possibility of establishing several campuses, inserting itself in the regional context, offering contributions and services resulting from teaching, applied research, and extension;

VIII - articulation and vertical integration among the different levels and modalities of education and horizontal integration with the productive sector and social segments, promoting opportunities for continuing education;

IX - dynamic and flexible organization, with an interdisciplinary focus, privileging permanent dialogue with the local and regional context, without abdicating scientific and technological expertise; and

$\mathrm{X}$ - maximizing the use of human resources and the use of existing infrastructure of the different levels and modalities of education.

In Article 3 (Brasil, 2005b), the goals are described:

I - develop technological education, understood as an essential dimension that goes beyond technical applications, interpreting technology as an educational and investigative process to which it can be generated and adapted to regional particularities;

II - apply technology, understood as the science of productive labor and labor as a category of knowledge and production; and

III - research technological solutions and develop technology management mechanisms, aiming at identifying innovative alternatives to solve social problems at the local and regional levels.

And in Article 4 (Brasil, 2005b), the objectives are outlined as:

I - to teach at the higher education level:

a) undergraduate and graduate courses, aiming at the formation of professionals for the different areas of technological education; and 
b) teaching degrees, as well as special pedagogical formation programs, aiming at the training of teachers and specialists for the disciplines in the various levels and modalities of education according to local and regional demands;

II - to offer technical courses that are primarily integrated with secondary school, aiming at the formation of technically capable citizens, according to local and regional demands;

III - to offer continuing education, through different mechanisms, aiming at the qualification, improvement, specialization, and upgrading of professionals, at all teaching levels, in the areas of technological education;

IV - to carry out research, stimulate creative activities and extend their benefits to the community, promote technological, social, economic, cultural, political, environmental development; and

$\mathrm{V}$ - develop extension activities according to the principles and purposes of technological education, in collaboration with the productive sector and society.

Article 5 states "UTFPR, observing the principle of inseparability between teaching, applied research, and extension, will organize its structure and mode of operation, under this law and the relevant legal rules".

Later, in the construction of the Institutional Political-Pedagogical Project (Projeto Político-Pedagógico Institucional; PPI), TU models from around the world were surveyed (i.e., German, Argentinian, North American, and French) (Universidade Tecnológica Federal do Paraná, 2007). UTFPR's strategic plan was strongly influenced by the French model, a country in which, historically, CEFET-PR had important partners. In the PPI, some influence of the German model is also notable (Universidade Tecnológica Federal do Paraná, 2007).

In the evaluation done during the construction of the PPI, the North American model, designed by the most prominent university system in the world, proved to be inconsistent with what was being proposed (Universidade Tecnológica Federal do Paraná, 2007). Although the best TUs in the world are American, based on the leading global rankings (Lievore \& Pilatti, 2018), and the inspiration of the new university proposed by the Lula government is compatible with the American model (of Flexnerian origin) (Borges \& Aquino, 2012), the main principle of American universities is market based, with a key focus on budgets. Certainly, such an orientation would significantly limit the relationship with other Brazilian public institutions.

Together, through the law to create UTFPR and the first PPI, the first TU in Brazil came to be. The absence of a previous model and an assessment of the current nature of the institution indicates that the model is still in construction. Nevertheless, the model adopted by UTFPR includes some constraints that ensure it remains distinct from traditional universities, but aligned with the internationally accepted idea of TU. These include an emphasis on technological education, a focus on real-world problems and local and regional socioeconomic development, orientation towards applied research, and collaboration with the productive sector. Shifts away from the initial proposal can be seen in the distancing from the technical courses which have tended to disappear. In practical terms, unlike the triad of teaching, research, and extension that serves as the foundation for the concept of the traditional university in Brazil, the proposal is built on a triad of technological education, applied research, and private sector partnerships. In terms of the latter, in France, a model used as a reference in the creation of UTFPR, these collaborations are presented in terms of technology transfer (Cechin, 2019; Lievore \& Pilatti, 2018).

From a legal perspective, nothing distinguishes UTFPR from other federal universities, i.e., there is no twotier HE system in Brazil. However, the absence of this distinction does pose legal problems for UTFPR. For example, it limits the possibility of including industry professionals as part of its faculty which would enable the institution to truly implement the concept of a TU as more practical and proximal to the productive sector, in other words, a real-world university. Even legislation that have brought about important advances, such as the Innovation Law, have been insufficient to produce concrete possibilities to effectively create a technology-oriented scenario. It is important to point out that distinctions do exist, for example, when 
comparing universities and IFs, but they are distinctions in terms of institutions that act at different levels of education.

Given that the line separating the classical from the technological university is tenuous, the pendular shift, particularly from the technological to the traditional, is probable. In Cunnane's (2018) terms, the institutions are on the brink of becoming tUs, with a lowercase t. Movement toward the traditional model is a concern demonstrated by UTFPR in its pedagogical projects (Universidade Tecnológica Federal do Paraná, 2014, 2019). Studies such as those by Lievore and Pilatti (2018) and Costa and collaborators (2019) demonstrate that there is a shift away from the model on which the institution was based. They also draw attention to policy and the definition of guidelines to create regular in-person courses linked to the Dean of Undergraduate and Professional Education, approved in the highest body of UTFPR (Universidade Tecnológica Federal do Paraná, 2018). The document is a clear attempt at correcting the current course of the institution. Evidently, it is possible to think of an institution that uses technology as a means, but in practice the reality does not always correspond with what is proposed. The absence of guiding models makes maintaining focus quite complex. Initiatives present in UTFPR's progeny, such as an entrepreneurship discipline in all courses, have been lost. The idea of practical courses has also fallen out of use. Comparisons between the courses offered at UTFPR with those offered at traditional universities almost always underscore their similarity.

One possible explanation lies in the perception that TUs are second-class institutions aimed at the underprivileged (Houghton, 2020). In contrast, traditional universities, with their long-standing history, are seen as having a superior status. For Lessa (2005, p. A18), "the University is not the scaffolding of national education, but its foundation [...]. It is the civilized mode of being, instead of the bayonet and the dominant currency". This perception, to some extent, explains the transition from schools for mechanics to HE in the country.

Currently, Bill No. 1.453 (Brasil, 2021) is in the Chamber of Deputies, and in essence, the project proposes to alter Law No. 11.892 (Brasil, 2008). In the proposal, one highlight is Art. 8, which increases the number of admissions in technical secondary school professional education courses from a minimum of 50 to $75 \%$. In the proposal, UTFPR is removed from the network. The bill can be interpreted as an attempt to swing the pendulum back from the network to secondary school education. In practical terms, if the bill is approved as proposed, the technical conditions for the creation of new TUs in Brazil will be limited.

\section{Final considerations}

TUs in many countries are considered similar to traditional universities; in others, there are significant statutory distinctions. The laws of each country, particularly the educational policies, play a determining role in establishing the profiles of these institutions. While there is no concept of TU that adequately encompasses the reality, the use of technology as a means or as an end is what characterizes this type of specialized university.

In Brazil, the trajectory to establish the first TU, UTFPR, was long, despite previous initiatives of long-term institutions with a focus on technology. Transformed from a CEFET, UTFPR was born out of the deconstruction of the technical education model in the country during the FHC government. However, the creation of UTFPR was not part of a national policy, and initiatives to establish new TUs have been abandoned politically. Federal Institutes were the political answer to pleas from several institutions during the PT government, and to date, no other government has changed this scenario.

In legal terms, there is no two-tier educational system in Brazil. Despite internal efforts, the legal apparatus and the pursuit of certain characteristics, such as world-class status, are leading UTFPR increasingly towards the configuration of classical universities. There is a tendency that only a new educational and political scenario can bring about the establishment of more TUs in Brazil. As in other sectors, the country is taking an approach that is contrary to global trends.

\section{References}

1. AMORIM, M. L. (2013). Exigência para o desenvolvimento das nossas indústrias: o ensino técnico no contexto da Lei Orgânica do Ensino Industrial. História da Educação, Porto Alegre, v. 17, n. 41, p. 123-138. DOI: http://dx.doi.org/10.1590/S2236-34592013000300008. Disponível em: 
https://www.scielo.br/j/heduc/a/TndPRSpmXM7kJ8qLk4fpxTs/?lang=pt\#. Acesso em: 18 nov. 2021.

2. BORGES, M. C.; AQUINO, O. F. (2012). Educação superior no Brasil e as políticas de expansão de vagas do Reuni: avanços e controvérsias. Educação: Teoria e Prática, Rio Claro, v. 22, n. 39, p. $117-$ 138. Disponível em:

https://www.periodicos.rc.biblioteca.unesp.br/index.php/educacao/article/view/4584. Acesso em: 18 nov. 2021.

3. Brasil. (1912). Ministerio da Fazenda. Relatório apresentado ao presidente da República dos Estados Unidos do Brazil pelo Dr. Francisco Salles Ministro de Estado dos Negócios da Fazenda no anno de 1912, 24º da República. Brasília, DF: Ministerio da Fazenda. v. 1910-1911. Disponível em: http://memoria.org.br/ia_visualiza_bd/ia_vdados.php? $\mathrm{cd}=\mathrm{meb} 000000390 \& \mathrm{~m}=3121 \& \mathrm{n}=\mathrm{rmfazenda19}$ 10e1911. Acesso em: 12 maio 2021.

4. BRASIL. (1937). Lei $n^{\circ}$ 378, de 13 de janeiro de 1937. Dá nova, organização ao Ministerio da Educação e Saude Publica. Brasília, DF: Presidência da República. Disponível em: https://www2.camara.leg.br/legin/fed/lei/1930-1939/lei-378-13-janeiro-1937-398059publicacaooriginal-1-pl.html. Acesso em: 18 nov. 2021.

5. BRASIL. (1942a). Decreto-Lei $n^{\circ} 4.127$, de 25 de fevereiro de 1942. Estabelece as bases de organização da rede federal de estabelecimentos de ensino industrial. Brasília, DF: Câmara dos Deputados. Disponível em: https://www2.camara.leg.br/legin/fed/declei/1940-1949/decreto-lei4127-25-fevereiro-1942-414123-publicacaooriginal-1-pe.html. Acesso em: 18 nov. 2021.

6. BRASIL. (1942b). Decreto-Lei $n^{\circ}$ 4.073, de 30 de janeiro de 1942. Lei orgânica do ensino industrial. Brasília, DF: Presidência da República. Disponível em:

https://www2.camara.leg.br/legin/fed/declei/1940-1949/decreto-lei-4073-30-janeiro-1942-414503publicacaooriginal-1-pe.html. Acesso em: 18 nov. 2021.

7. BRASIL. (1959a). Decreto $n^{\circ} 47.038$, de 16 de outubro de 1959. Aprova o Regulamento do Ensino Industrial. Brasília, DF: Presidência da República. Disponível em: http://www.planalto.gov.br/ccivil_03/decreto/1950-1969/d47038.htm. Acesso em: 18 nov. 2021.

8. BRASIL. (1959b). Lei $n^{\circ} 3.552$, de 16 de fevereiro de 1959. Dispõe sobre nova organização escolar e administrativa dos estabelecimentos de ensino industrial do Ministério da Educação e Cultura, e dá outras providências. Brasília, DF: Presidência da República. Disponível em:

http://www.planalto.gov.br/ccivil_03/leis/L3552.htm. Acesso em: 18 nov. 2021.

9. BRASIL. (1969). Decreto-Lei $n^{\circ}$ 547, de 18 de abril de 1969. Autoriza a organização e o funcionamento de cursos profissionais superiores de curta duração. Brasília, DF: Presidência da República. Disponível em: http://www.planalto.gov.br/ccivil_03/decreto-lei/1965-1988/del0547.htm. Acesso em: 18 nov. 2021.

10. BRASIL. (1978). Lei $n^{o}$ 6.545, de 30 de junho de 1978. Dispõe sobre a transformação das Escolas Técnicas Federais de Minas Gerais, do Paraná e Celso Suckow da Fonseca em Centros Federais de Educação Tecnológica e dá outras providências. Brasília, DF: Presidência da República. Disponível em: http://www.planalto.gov.br/ccivil_03/LEIS/L6545.htm. Acesso em: 18 nov. 2021.

11. BRASIL. (1982). Decreto $n^{\circ} 87.310$, de 21 de junho de 1982. Regulamenta a Lei $n^{0} 6.545$, de 30 de junho de 1978, e dá outras providências. Brasília, DF: Presidência da República. Disponível em: http://www.planalto.gov.br/ccivil_03/decreto/1980-1989/d87310.htm. Acesso em: 18 nov. 2021.

12. BRASIL. (1989). Lei $n^{\circ} 7.863$, de 31 de outubro de 1989. Dispõe sobre a transformação da Escola Técnica Federal do Maranhão em Centro Federal de Educação Tecnológica. Brasília, DF:

Presidência da República. Disponível em: http://www.planalto.gov.br/ccivil_03/leis/1989_1994/17863.htm. Acesso em: 18 nov. 2021.

13. BRASIL. (1993a). Lei $n^{\circ}$ 8.670, de 30 de junho de 1993. Dispõe sobre a criação de Escolas Técnicas e Agrotécnicas Federais e dá outras providências. Diário Oficial da União: seção 1, Brasília, DF, n. 123, p. 1. Disponível em: https://pesquisa.in.gov.br/imprensa/jsp/visualiza/index.jsp?jornal=1\&pagina=1\&data=01/07/1993. Acesso em: 18 nov. 2021.

14. BRASIL. (1993b). Lei n ${ }^{\circ}$ 8.711, de 28 de setembro de 1993. Dispõe sobre a transformação da Escola Técnica Federal da Bahia em Centro Federal de Educação Tecnológica e dá outras providências. Diário Oficial da União: seção 1, Brasília, DF, n. 186, p. 14533. Disponível em: 
https://pesquisa.in.gov.br/imprensa/jsp/visualiza/index.jsp?.jornal=1\&pagina=1\&data=29/09/1993. Acesso em: 18 nov. 2021.

15. BRASIL. (1994). Lei ${ }^{\circ}$ 8.948, de 8 de dezembro de 1994. Dispõe sobre a instituição do Sistema Nacional de Educação Tecnológica e dá outras providências. Diário Oficial da União: seção 1, Brasília, DF, n. 233, p. 18882. Disponível em: https://pesquisa.in.gov.br/imprensa/jsp/visualiza/index.jsp?jornal=1\&pagina=2\&data=09/12/1994. Acesso em: 18 nov. 2021.

16. BRASIL. (1997). Decreto $n^{0} 2.208$, de 17 de abril de 1997. Regulamenta o $§ 22$ do art. 36 e os arts. 39 a 42 da Lei $n^{\circ}$ 9.394, de 20 de dezembro de 1996, que estabelece as diretrizes e bases da educação nacional. Diário Oficial da União: seção 1, Brasília, DF, n. 74, p. 7760-7761. Disponível em: https://pesquisa.in.gov.br/imprensa/jsp/visualiza/index.jsp?jornal=1\&pagina=4\&data=18/04/1997. Acesso em: 18 nov. 2021.

17. BRASIL. (2004). Decreto $n^{0} 5.224$, de 01 de outubro de 2004. Dispõe sobre a organização dos Centros Federais de Educação Tecnológica e dá outras providências. Diário Oficial da União: seção 1, Brasília, DF, n. 191, p. 3-5. Disponível em: https://pesquisa.in.gov.br/imprensa/jsp/visualiza/index.jsp?data=04/10/2004\&jornal=1\&pagina=3\&t otalArquivos $=96$. Acesso em: 18 nov. 2021.

18. BRASIL. (2005a). Lei de Diretrizes e Bases da Educação Nacional. Brasília, DF: Senado Federal, Coordenação de Edições Técnicas. Disponível em:

https://www2.senado.leg.br/bdsf/bitstream/handle/id/70320/65.pdf. Acesso em: 18 nov. 2021.

19. BRASIL. (2005b). Lei ${ }^{\circ} 11.184$, de 7 de outubro de 2005. Dispõe sobre a transformação do Centro Federal de Educação Tecnológica do Paraná em Universidade Tecnológica Federal do Paraná e dá outras providências. Diário Oficial da União: seção 1, Brasília, DF, n. 195, p. 1-2. Disponível em: https://pesquisa.in.gov.br/imprensa/jsp/visualiza/index.jsp?jornal=1\&pagina=1\&data=10/10/2005. Acesso em: 18 nov. 2021.

20. BRASIL. (2007). Decreto $n^{0} 6.095$, de 24 de abril de 2007. Estabelece diretrizes para o processo de integração de instituições federais de educação tecnológica, para fins de constituição dos Institutos Federais de Educação, Ciência e Tecnologia - IFET, no âmbito da Rede Federal de Educação Tecnológica. Diário Oficial da União: seção 1, Brasília, DF, n. 79, p. 6-7. Disponível em: https://pesquisa.in.gov.br/imprensa/jsp/visualiza/index.jsp?jornal=1\&pagina=6\&data=25/04/2007. Acesso em: 18 nov. 2021.

21. BRASIL. (2008). Lei ${ }^{0} 11.892$, de 29 de dezembro de 2008. Institui a Rede Federal de Educação Profissional, Científica e Tecnológica, cria os Institutos Federais de Educação, Ciência e Tecnologia, e dá outras providências. Diário Oficial da União: seção 1, Brasília, DF, n. 253, p. 1-3. Disponível em:

https://pesquisa.in.gov.br/imprensa/jsp/visualiza/index.jsp?jornal=1\&pagina=1\&data=30/12/2008. Acesso em: 18 nov. 2021.

22. BRASIL. (2016). [Constituição (1988)]. Constituição da República Federativa do Brasil. Texto constitucional promulgado em 5 de outubro de 1988, com as alterações determinadas pelas Emendas Constitucionais de Revisão nos 1 a 6/94, pelas Emendas Constitucionais nos 1/92 a 91/2016 e pelo Decreto Legislativo no 186/2008. Brasília, DF: Senado Federal. Disponível em: https://www2.senado.leg.br/bdsf/bitstream/handle/id/518231/CF88_Livro_EC91_2016.pdf. Acesso em: 18 nov. 2021.

23. Brasil. (2017). Lei de Diretrizes e Bases da Educação Nacional. Brasília, DF: Senado Federal. Disponível em: https://www2.senado.leg.br/bdsf/bitstream/handle/id/70320/65.pdf. Acesso em: 28 mar. 2021.

24. BRASIL. (2021). Projeto de Lei $n^{o} 1.453 / 2021$. Altera a Lei $n^{0} 11.892$, de 28 de dezembro de 2008, que institui a Rede Federal de Educação Profissional, Científica e Tecnológica, cria os Institutos Federais de Educação, Ciência e Tecnologia, e dá outras providências, para expandir a inovação e o alcance dos cursos técnicos, promover estratégias para a profissionalização e estimular o emprego. Brasília, DF: Câmara dos Deputados. Disponível em: https://www.camara.leg.br/propostaslegislativas/2278542. Acesso em: 18 nov. 2021.

25. BRAZIL. (1909). Decreto $n^{\circ}$ 7.566, de 23 de setembro de 1909. Crêa nas capitaes dos Estados da Republica Escolas de Aprendizes Artifices, para o ensino profissional primario e gratuito. Rio de 
Janeiro: Câmara dos Deputados. Disponível em: https://www2.camara.leg.br/legin/fed/decret/19001909/decreto-7566-23-setembro-1909-525411-publicacaooriginal-1-pe.html. Acesso em: 18 nov. 2021.

26. BRITO CRUZ, C. H. (2010). Ciência, tecnologia e inovação no Brasil: desafios para o período 2011 a 2015. Revista Interesse Nacional, São Paulo. Disponível em:

https://www.ifi.unicamp.br/ brito/artigos/CTI-desafios-InteresseNacional-07082010-FINAL.pdf. Acesso em: 18 nov. 2021.

27. CECHIN, M. R. (2019). Estudo comparativo entre a Universidade Tecnológica Federal do Paraná e as universidades de Tecnologia da França. 2019. Tese (Doutorado em Ensino de Ciência e Tecnologia) - Universidade Tecnológica Federal do Paraná, Ponta Grossa. Disponível em: http://repositorio.utfpr.edu.br/jspui/handle/1/4041. Acesso em: 18 nov. 2021.

28. CECHIN, M. R.; PILATTI, L. A.; RAMOND, B. (2021). Maio de 68: contribuições para nascer a primeira universidade de tecnologia na França. Cadernos de História da Educação, Uberlândia, v. 20, e013. DOI: https://doi.org/10.14393/che-v20-2021-13. Disponível em: http://www.seer.ufu.br/index.html. Acesso em: 18 nov. 2021.

29. CHIARINI, T.; VIEIRA, K. P. (2012). Universidades como produtoras de conhecimento para o desenvolvimento econômico: sistema superior de ensino e as políticas de CT\&I. Revista Brasileira de Economia, Rio de Janeiro, v. 66, n. 1, p. 117-132. DOI: https://doi.org/10.1590/S003471402012000100006. Disponível em:

https://www.scielo.br/j/rbe/a/hZq7bsMskm3Qp9qmxt98Qfs/?lang=pt. Acesso em: 18 nov. 2021.

30. CIAVATTA, M. (2006). Os Centros Federais de Educação Tecnológica e o ensino superior: duas lógicas em confronto. Educação \& Sociedade, Campinas, v. 27, n. 96, p. 911-934. DOI: https://doi.org/10.1590/S0101-73302006000300013. Disponível em: https://www.scielo.br/j/es/a/T6jddTXTVjNSzR5mxB6v7cB/?lang=pt. Acesso em: 18 nov. 2021.

31. COSTA, A. da et al. (2019). Perfil dos docentes de jovens universidades brasileiras: estudo comparativo entre UTFPR e UFABC. Revista Brasileira de Ensino de Ciência e Tecnologia, Ponta Grossa, v. 12, n. 1, p. 523-538. DOI: http://dx.doi.org/10.3895/rbect.v12n1.9575. Disponível em: https://periodicos.utfpr.edu.br/rbect/article/view/9575. Acesso em: 18 nov. 2021.

32. CUNHA, L. A. (2000). O ensino industrial-manufatureiro no Brasil. Revista Brasileira de Educação, Rio de Janeiro, n. 14, p. 89-107. Disponível em:

https://www.scielo.br/j/rbedu/a/FNsjBnkcM5S5dPpbSgwNPGB/abstract/?lang=pt. Acesso em: 18 nov. 2021.

33. CUNHA, L. A. (2003). O ensino superior no octênio FHC. Educação \& Sociedade, Campinas, v. 24, n. 82, p. 37-61. DOI: https://doi.org/10.1590/S0101-73302003000100003. Disponível em: https://www.scielo.br/j/es/a/kLKQrxCM8hVbjsQ5vs4SY9n/?lang=pt. Acesso em: 18 nov. 2021.

34. CUNHA, M. V. da. (2002). A educação no período Kubitschek: os centros de pesquisas do Inep. Revista Brasileira de Estudos Pedagógicos, Brasília, DF, v. 83, n. 203/204/205, p. 127-140. DOI: https://doi.org/10.24109/2176-6681.rbep.83i203-04-05.909. Disponível em: http://rbep.inep.gov.br/ojs3/index.php/rbep/article/view/1368. Acesso em: 18 nov. 2021.

35. CUNNANE, V. (2018). Technological universities should bring out the best of both sectors. The University Times, Dublin. Disponível em: http://www.universitytimes.ie/2018/09/technologicaluniversities-should-bring-out-the-best-of-both-sectors/. Acesso em: 18 nov. 2021.

36. DOERN, B. (2008). Polytechnics in higher education systems: a comparative review and policy implications for Ontario. Toronto: The Higher Education Quality Council of Ontario. Disponível em: https://heqco.ca/pub/polytechnics-in-higher-education-systems-a-comparative-review-and-policyimplications-for-ontario/. Acesso em: 18 nov. 2021.

37. DU PRÉ, R. Universities of technology in the context of the South African higher education landscape. In: TOWNSEND, R. (ed). (2010). Universities of technology: deepening the debate. South Africa: South African Council on Higher Education. p. 1-41. Disponível em: https://cms.cut.ac.za/Files/Froala/bb2e79f0-7d35-4112-9a0a-6afcb8b5200c.pdf. Acesso em: 18 nov. 2021.

38. DUMONT, A. S. (1918). O que eu vi, o que nós veremos. [S. l.: s. n.]. Disponível em: http://www.portugues.seed.pr.gov.br/arquivos/File/leit_online/santos_dumond.pdf. Acesso em: 18 nov. 2021. 
39. FGV CPDOC. A Era Vargas: dos anos 20 a 1945. Disponível em: https://cpdoc.fgv.br/producao/dossies/AEraVargas1/anos3745/EducacaoCulturaPropaganda/UniversidadeBrasil. Acesso em: 18 nov. 2021.

40. FORJAZ, M. C. S. (2005). As origens da Embraer. Tempo Social, São Paulo, v. 17, n. 1, p. 281-298. DOI: https://doi.org/10.1590/S0103-20702005000100012. Disponível em: https://www.scielo.br/j/ts/a/WSQycbJRGX9cS8BH865W5NQ/?lang=pt. Acesso em: 18 nov. 2021.

41. GIORGI, M. C.; ALMEIDA, F. S. de. (2014). Ensino profissional no Brasil: diálogos com a ditadura militar. Opsis, Catalão, v. 14, n. 1, p. 262-281. DOI: https://doi.org/10.5216/o.v14i1.29000. Disponível em: https://www.revistas.ufg.br/index.php/Opsis/article/view/29000. Acesso em: 18 nov. 2021.

42. GUIMARÃES, A. A. (2002). A concepção e o modelo de universidade dos cursos superiores de tecnologia do Centro Federal de Educação Tecnológica do Paraná: o caso da unidade de Ponta Grossa. 2002. Dissertação (Mestrado em Tecnologia) - Centro Federal de Educação Tecnológica do Paraná, Curitiba.

43. HARKIN, S.; HAZELKORN, E. Institutional mergers in Ireland. In: CURAJ, A. et al. (ed.). (2015). Mergers and alliances in higher education: international practice and emerging opportunities. Dordrecht, Netherlands: Springer. p. 105-121. DOI: https://doi.org/10.1007/978-3-319-13135-1_6. Disponível em: https://link.springer.com/chapter/10.1007\%2F978-3-319-13135-1_6. Acesso em: 18 nov. 2021.

44. HATTON, E. J. (2002). Charles Sturt University: a case study of institutional amalgamation. Higher Education, Switzerland, v. 44, p. 5-27. DOI: https://doi.org/10.1023/A:1015504909483. Disponível em: https://link.springer.com/article/10.1023\%2FA\%3A1015504909483. Acesso em: 18 nov. 2021.

45. HAYHOE, R. (1989). China's universities and Western academic models. Higher Education, Switzerland, v. 18, p. 49-85. DOI: https://doi.org/10.1007/BF00138961. Disponível em: https://link.springer.com/article/10.1007\%2FBF00138961. Acesso em: 18 nov. 2021.

46. HELMANN, C. L. (2019). Universidade Tecnológica Federal do Paraná e Instituto Politécnico de Bragança: um estudo comparativo. 2019. Tese (Doutorado em Ensino de Ciência e Tecnologia) Universidade Tecnológica Federal do Paraná, Ponta Grossa. Disponível em: http://repositorio.utfpr.edu.br:8080/jspui/handle/1/4148. Acesso em: 18 nov. 2021.

47. HIGHER EDUCATION AUTHORITY. (2019). A spatial \& socio-economic profile of higher education institutions in Ireland. Dublin: Higher Education Authority.

48. HOUGHTON, F. (2020). Technological universities in Ireland: the new imperative. Irish Journal of Academic Practice, Dublin, v. 8, n. 1, art. 12. Disponível em: https://arrow.tudublin.ie/ijap/vol8/iss1/12/. Acesso em: 18 nov. 2021.

49. INSTITUTO MILITAR DE ENGENHARIA. História: tradição e qualidade. Disponível em: http://www.ime.eb.mil.br/pt/historia.html. Acesso em: 18 nov. 2021.

50. INSTITUTO TECNOLÓGICO DE AERONÁUTICA. O ITA: história e valores. Disponível em: http://www.ita.br/aconcepcao. Acesso em: 18 nov. 2021.

51. KYVIK, S. (2002). The merger of non-university colleges in Norway. Higher Education, Switzerland, v. 44, p. 53-72. DOI: https://doi.org/10.1023/A:1015561027230. Disponível em: https://link.springer.com/article/10.1023\%2FA\%3A1015561027230. Acesso em: 18 nov. 2021.

52. LAYA, M. S. Technological universities: a relevant educational model for Mexico? In: RABY, R. L.; VALEAU, E. J. (ed.). (2009). Community College Models. Dordrecht: Springer. p. 219-233. DOI: https://doi.org/10.1007/978-1-4020-9477-4_13. Disponível em: https://link.springer.com/chapter/10.1007\%2F978-1-4020-9477-4_13. Acesso em: 18 nov. 2021.

53. LÉDA, D.; MANCEBO, D. (2009). REUNI: heteronomia e precarização da universidade e do trabalho docente. Educação \& Realidade, Porto Alegre, v. 34, n. 1, p. 49-64. Disponível em: https://seer.ufrgs.br/educacaoerealidade/article/view/8457. Acesso em: 18 nov. 2021.

54. LESSA, C. (2005). Universidade pública e nação. Entrevista. Jornal do Brasil, Rio de Janeiro, Economia \& Negócios, p. A18. Disponível em: https://www2.senado.leg.br/bdsf/bitstream/handle/id/64742/noticia.htm?sequence=1\&isAllowed=y. Acesso em: 18 nov. 2021. 
55. LEWIS, M. S. (1992). The polytechnics: a peculiarly British phenomenon. Metropolitan Universities, Towson, v. 2, n. 4, p. 24-34. Disponível em:

https://journals.iupui.edu/index.php/muj/article/view/19224/19049. Acesso em: 18 nov. 2021.

56. LIEVORE, C.; PILATTI, L. A. (2018). Entre o tecnológico e o clássico: o modelo de universidade da UTFPR. Trabalho \& Educação, Belo Horizonte, v. 27, n. 1, p. 135-159. Disponível em: https://periodicos.ufmg.br/index.php/trabedu/article/view/9725. Acesso em: 18 nov. 2021.

57. LIEVORE, C.; PILATTI, L. A.; TEIXEIRA, J. A. S. (2021a). Shaping for the future: professionalizing higher education and implications on the scientific policies of Brazil and Portugal. SN Social Sciences, Switzerland, v. 1, art. 17. DOI: https://doi.org/10.1007/s43545-020-00019-z. Disponível em: https://link.springer.com/article/10.1007\%2Fs43545-020-00019-z. Acesso em: 18 nov. 2021.

58. LIEVORE, C.; PILATTI, L. A.; TEIXEIRA, J. A. S. (2021b). Universities of applied sciences in Brazil and in Portugal from conception to practice. Interchange, Toronto, v. 52, p. 115-132. DOI: https://doi.org/10.1007/s10780-020-09412-2. Disponível em: https://link.springer.com/article/10.1007\%2Fs 10780-020-09412-2. Acesso em: 18 nov. 2021.

59. MARINHA DO BRASIL. A Escola Naval. Rio de Janeiro. Disponível em: https://www.marinha.mil.br/sites/www.marinha.mil.br.en/files/upload/historia_en.pdf. Acesso em: 18 nov. 2021.

60. MCKENNA, S.; SUTHERLAND, L. (2006). Balancing knowledge construction and skills training in universities of technology. Perspectivies in Education, Bloemfontein, v. 24, n. 3, p. 15-24. Disponível em: https://journals.co.za/doi/10.10520/EJC87394. Acesso em: 18 nov. 2021.

61. MILDRED, G. (2002). Launching the Unified National System: What happened in South Australia. Higher Education, Switzerland, v. 44, p. 29-51. DOI: https://doi.org/10.1023/A:1015556910392. Disponível em: https://link.springer.com/article/10.1023\%2FA\%3A1015556910392. Acesso em: 18 nov. 2021.

62. NORGÅRD, J. D.; SKODVIN, O.-J. (2002). The importance of geography and culture in mergers: a Norwegian institutional case study. Higher Education, Switzerland, v. 44, p. 73-90. DOI: https://doi.org/10.1023/A:1015513111300. Disponível em: https://link.springer.com/article/10.1023/A:1015513111300. Acesso em: 18 nov. 2021.

63. PILATTI, L. A. (2017). Internalização da interdisciplinaridade como condição para a internacionalização da Universidade Tecnológica Federal do Paraná - UTFPR. In: PHILIPPI JR, A.; FERNANDES, V.; PACHECO, R. C. S. (org.). Ensino, pesquisa e inovação: desenvolvendo a interdisciplinaridade. Barueri: Manole. p. 102-119.

64. PILATTI, L. A.; LIEVORE, C. (2018a). Redes de universidades: o caso da RUTyP. Educación Superior y Sociedad, Caracas, v. 28, n. 28, p. 127-154. Disponível em: https://www.iesalc.unesco.org/ess/index.php/ess3/article/view/87. Acesso em: 18 nov. 2021.

65. PILATTI, L. A.; LIEVORE, C. (2018b). Universidades tecnológicas: o que induziu esse modelo universitário no Brasil. Revista Brasileira de Ensino de Ciência e Tecnologia, Ponta Grossa, v. 11, n. 2, p. 582-613. DOI: http://dx.doi.org/10.3895/rbect.v11n2.8471. Disponível em: https://periodicos.utfpr.edu.br/rbect/article/view/8471. Acesso em: 18 nov. 2021.

66. PINTO, J. M. de R. (2002). Financiamento da educação no Brasil: um balanço do governo FHC (1995-2002). Educação \& Sociedade, Campinas, v. 23, n. 80, p. 108-135. DOI: https://doi.org/10.1590/S0101-73302002008000008. Disponível em: https://www.scielo.br/j/es/a/n8yyYhkgNfStcVrkBNXycXG/?lang=pt. Acesso em: 18 nov. 2021.

67. PRATT, L. (1997). The polytechnic experiment: 1965-1992. Buckingham: Open University Press. Disponível em: https://archive.org/details/ERIC_ED415724. Acesso em: 18 nov. 2021.

68. PROCESS and criteria for designation as a technological university. Disponível em: https://www.education.ie/en/The-Education-System/Higher-Education/Process-and-Criteria-forDesignation-as-a-Technological-University.pdf. Acesso em: 18 abr. 2021.

69. RED DE UNIVERSIDADES TECNOLÓGICAS Y POLITÉCNICAS DA AMÉRICA LATINA Y EL CARIBE. (2017). Ejes estratégicos. Disponível em: https://www.redutyp.org/. Acesso em: 18 nov. 2021.

70. SANTOS, F. S.; NASCIMENTO, E. P. do; BUARQUE, C. (2013). Mudanças necessárias na universidade brasileira: autonomia, forma de governo e internacionalização. Educação em Revista, 
Belo Horizonte, v. 29, n. 1, p. 39-61. DOI: https://doi.org/10.1590/S0102-46982013000100004. Disponível em: https://www.scielo.br/j/edur/a/Xsc35pyPCdZNfTRjsyNKr8d/?lang=pt. Acesso em: 18 nov. 2021.

71. SCHNEIDER, B. R. (2015). The developmental state in Brazil: comparative and historical perspectives. Brazilian Journal of Political Economy, São Paulo, v. 35, n. 1, p. 114-132. DOI: https://doi.org/10.1590/0101-31572015v35n01a07. Disponível em: https://www.scielo.br/j/rep/a/JHVdt63NTjQ3pKSJFpxpntb/?lang=en. Acesso em: 18 nov. 2021.

72. UNIVERSIDADE DO BRASIL. (1958). Escola Nacional de Química. Anuário 1957. Disponível em: http://www.ambientesquimicos.eq.ufrj.br/Nosso_ambito_1_files/1957-

AnuariodaEscolaNacionaldeQuimicadaUniversidadedoBrasil.pdf. Acesso em: 18 nov. 2021.

73. UNIVERSIDADE FEDERAL DE ITAJUBÁ. História. Disponível em: https://unifei.edu.br/institucional/historia/. Acesso em: 18 nov. 2021.

74. UNIVERSIDADE TECNOLÓGICA FEDERAL DO PARANÁ. (2007). Projeto PolíticoPedagógico Institucional (PPI). Curitiba: UTFPR. Disponível em: http://www2.td.utfpr.edu.br/eng_civil/pdf/ppi.pdf. Acesso em: 18 nov. 2021.

75. UNIVERSIDADE TECNOLÓGICA FEDERAL DO PARANÁ. (2014). Plano de Desenvolvimento Institucional: 2013-2017. Curitiba: UTFPR. Disponível em:

http://portal.utfpr.edu.br/documentos/reitoria/documentos-institucionais/pdi/pdi_2013-2017. Acesso em: 18 nov. 2021.

76. UNIVERSIDADE TECNOLÓGICA FEDERAL DO PARANÁ. (2018). Política e definição de diretrizes para criação de cursos regulares presenciais vinculados a Pró-Reitoria de Graduação e Educação Profissional - PROGRAD/UTFPR. Curitiba: UTFPR. Disponível em: https://cloud.utfpr.edu.br/index.php/s/DoCD8aBfVN6tsfl. Acesso em: 18 nov. 2021.

77. UNIVERSIDADE TECNOLÓGICA FEDERAL DO PARANÁ. (2019). Projeto Pedagógico Institucional (PPI) da Universidade Tecnológica Federal do Paraná. Curitiba: UTFPR. Disponível em: https://cloud.utfpr.edu.br/index.php/s/Z3pqMqWkxbsCbLz. Acesso em: 18 nov. 2021. 